\title{
Debunking the Myths of Vision and Mission Statements: A Content Analysis of FT Ranked Top 100 Business Schools
}

\author{
Dr Kamran Ahmed Siddiqui, ${ }^{1, *}$ \\ ${ }^{1}$ College of Business Administration, Imam Abdulrahman Bin Faisal University, Saudi Arabia.
}

\begin{abstract}
The purpose of this paper is to answer seven famous myths about vision and mission statements by analysing the vision and mission statements of FT Ranked Top 100 Business Schools in the world. First myth states that all business schools have both vision and mission statements. Second myth says both mission and vision statements are equal in length. Third myth states that all nine components must be present in all mission statements. Fourth myth assumes faculty is the hallmark of business school's mission. Fifth myth states technology is at the centre stage of business school's mission. Sixth myth assumes research is not part of business school's mission. Finally, seventh myth says leadership is no more part of business school's mission. FT ranking for Top 100 Business Schools was selected for this study and business school's vision and mission statements were collected from their official websites. Content analysis was used as the major data analysis technique. Data analyses using descriptive statistics proved all seven myths wrong.
\end{abstract}

\section{Introduction}

World's top business schools [1] have similarities and differences in their focuses, roles and functions [2]. These differentiations are reflected in their strategic planning especially their crucial elements of strategic planning e.g., vision and mission statements [3][4]. Vision statements normally explains the long-term goals of the university and these statements control and guide the future practices [4]. On the other hand, mission statements reflect the reason for being an organization. These statements eventually guide the functions of the organization [4].

\section{Methods}

Top-100 business school were selected for this study based on FT ranking [1]. Business school's vision and mission statements were collected from their official websites. This technique of collecting vision/mission statements through official websites is quite common in earlier studies on vision/mission statements of universities [2][3][4][5], medical schools [6], law schools [7], non-profit education institutions [8] or even in business schools [9].

\footnotetext{
* Corresponding author: KASiddiqui@iau.edu.sa
} 
This study employs Content Analysis, as it is commonly used technique in contemporary business studies. It provides opportunity to collect verbal, print and electronic data by both ways qualitatively and quantitatively [10]. Content analysis or textual analysis is "any technique of making inferences by objectively and systematically identifying specified characteristics of messages" [11]. In other words, it is "summarizing, quantitative analysis of messages that relies on scientific method (including attention to objectivity, inter subjectivity, priori design, reliability, and hypothesis testing) and is not limited as to the types of variables that may be measured or the context in which the messages are created or presented" [12]. In the literature, content analysis has been extensively used in analysing mission statements for example in different industries in USA [13]; in cross-country analyses [14]; in public libraries [15]. Even in academia, many studies on mission statement have used content analysis for example in top 100 global brands [16]; in social work school [17]; or even in engineering schools [18]. Content analysis has also been used in many studies focused on analyzing university's vision/mission statements [19][20] [21]; in FT ranked European Business Schools [22] and even in AACSB-accredited schools [23]. The framework used in this study to analyse mission statements is based on the 9 possible components and 10 characteristics of mission statements. It also involves 10 components of vision statements. This study used the components and characteristics of mission statements and components of vision statements and their operational definitions; possible explanations keywords as coding schemes taken from earlier studies [24]. This framework of nine components has extensively been used in earlier to analyse mission statements [22][16].

\section{Results and Discussion}

This study provides four sets of analyses on mission and vision statement including (1) Word count and Vocabulary density; (2) Frequently used keywords; (3) Major themes in mission statements; (4) Examination of components and characteristics of mission statements.

Table 1 presents a comparison of vision and mission statements based on the word and vocabulary density of mission and vision statements. This table suggest that vision statements are shorter in length (average number of words $=47$ ) as compared to corresponding mission statement (average number of words $=63$ ). Table 4 also suggest that vision statements have higher vocabulary density $(0.32)$ as compared to corresponding mission statements $(0.226)$. Vision statements having relatively higher vocabulary density indicates simpler text with words reused.

Table 1 Word count and Vocabulary density: Comparisons of Vision and Mission statements

\begin{tabular}{|l|c|c|}
\hline \multicolumn{1}{|c|}{ Word Count \& Vocabulary Density } & Vision Statement & Mission Statement \\
\hline Total Number of Words & 2539 & 5751 \\
\hline Average Number of Words & 47 & 63 \\
\hline Minimum Number of Words & 3 & 9 \\
\hline Maximum Number of Words & 200 & 304 \\
\hline Unique Number of Words & 812 & 1299 \\
\hline Vocabulary Density & 0.320 & 0.226 \\
\hline
\end{tabular}


Table 2 provides a list of top five frequently keywords in vision and missions statements. Four keywords are common in both vision and mission statements including 'business', 'research', 'leader', and 'world'. Two keywords are distinct; 'students' appeared among vision statement and 'knowledge' appeared more in mission statements.

Table 2 Most frequently used keywords in vision and mission statements

\begin{tabular}{|c|c|}
\hline Vision Statement & Mission Statement \\
\hline Business (50) & Business (92) \\
\hline Research (28) & Leaders (62) \\
\hline World (26) & Research (60) \\
\hline Leaders (21) & World (52) \\
\hline Students (19) & Knowledge (44) \\
\hline
\end{tabular}

Table 3 presents components of mission statements with frequency of occurrence. It suggest that not all nine components of mission statements are fully replicated in FT Ranked Top 100 Business school's mission statements. Highest frequency is for 'Concern for public image'.

Table 3 Components of Mission Statements with Frequency

\begin{tabular}{|l|c|}
\hline \multicolumn{1}{|c|}{ Components of Mission Statements } & Frequency \\
\hline Concern for Public Image & 53 \\
\hline Products or Services & 39 \\
\hline Markets & 39 \\
\hline Customers & 27 \\
\hline Concern for Survival, Growth, Profitability & 15 \\
\hline Concern for Employees & 13 \\
\hline Self-Concept & 10 \\
\hline Philosophy & 7 \\
\hline Technology & 4 \\
\hline
\end{tabular}

Table 4 presents selected characteristics of mission statements i.e., Social responsibility and Environmental responsibility. Rest of characteristics of mission statements and all components of vision statements does not show any variance. It shows a significant number of business schools are committed towards social responsibility. Interestingly 16 business schools have shown social responsibility in their vision statements. Ironically, environmental responsibility has not been reflected by any top 100 business school in their mission or vision statements.

Table 4 Selected Characteristics of Mission Statements with Frequency

\begin{tabular}{|l|c|}
\hline \multicolumn{1}{|c|}{ Components of Mission Statements } & Frequency \\
\hline Socially Responsible 16 & 45 \\
\hline Environmentally responsible 0 & 0 \\
\hline
\end{tabular}


Based on the presence of vision and/or mission statement FT ranked top 100 Business Schools classified into three clusters (Fig. 1). Cluster 1 include business schools having Mission Statements only. 47 business schools fall in this category while average rank is 43 (Table 5). Cluster 2 include business schools having both mission and vision statements. 44 business schools fall into this category and their average rank is 56 (Table 6). Cluster 3 include business schools having vision statements only. This seems to be smallest cluster as compared to other two having only 9 business schools listed in this category with an average rank is 58 (Table 7). It means business schools having only mission statement relatively higher rank as compared to other two clusters.

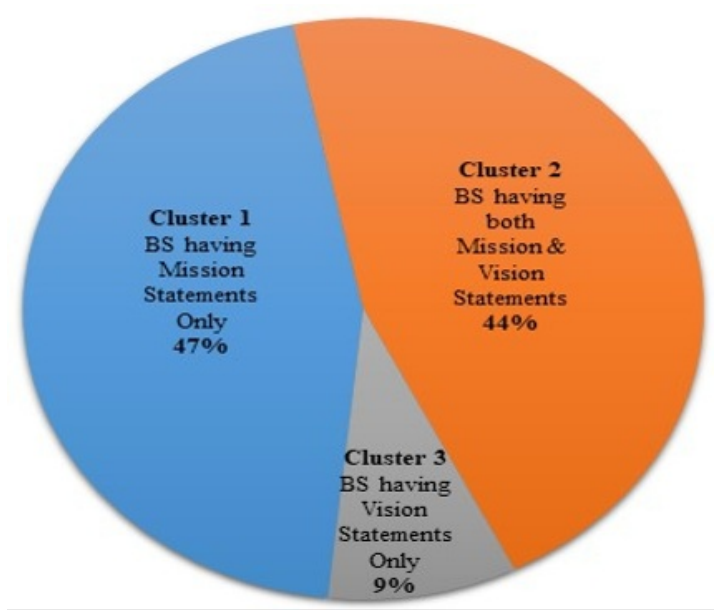

Fig. 1. Clusters of Business Schools based on Vision and Mission Statements 
Table 5 Cluster 1 - Business Schools having Mission Statement Only

\begin{tabular}{|c|c|c|}
\hline $\begin{array}{c}\text { FT Rank } \\
2020\end{array}$ & Business School \& University & Country \\
\hline 1 & Harvard Business School & US \\
\hline 2 & University of Pennsylvania: Wharton & US \\
\hline 3 & Stanford Graduate School of Business & US \\
\hline 4 & Insead & France \\
\hline 6 & MIT: Sloan & US \\
\hline 7 & London Business School & UK \\
\hline 8 & Columbia Business School & US \\
\hline 10 & University of Chicago: Booth & US \\
\hline 11 & Northwestern University: Kellogg & US \\
\hline 12 & University of California at Berkeley: Haas & US \\
\hline 14 & Yale School of Management & US \\
\hline 16 & Duke University: Fuqua & US \\
\hline 18 & University of Virginia: Darden & US \\
\hline 19 & University of Cambridge: Judge & UK \\
\hline 19 & HKUST Business School & China \\
\hline 21 & University of Oxford: Saïd & $\mathrm{UK}$ \\
\hline 22 & New York University: Stern & US \\
\hline 24 & Esade Business School & Spain \\
\hline 25 & UCLA Anderson School of Management & US \\
\hline 29 & SDA Bocconi School of Management & Italy \\
\hline 30 & University of Michigan: Ross & US \\
\hline 31 & Georgetown University: McDonough & US \\
\hline 34 & University of Florida: Warrington & US \\
\hline 35 & Nanyang Business School, NTU Singapore & Singapore \\
\hline 36 & University of Southern California: Marshall & US \\
\hline 45 & Vanderbilt University: Owen & US \\
\hline 47 & Emory University: Goizueta & US \\
\hline 47 & University of Washington: Foster & US \\
\hline 50 & City Business School (Cass), University of London & UK \\
\hline 54 & Sungkyunkwan University GSB & S Korea \\
\hline 57 & Rice University: Jones & US \\
\hline 63 & Singapore Management University: Lee Kong Chian & Singapore \\
\hline 66 & Rotterdam School of Management, Erasmus University & Netherlands \\
\hline 70 & George Washington University & US \\
\hline 72 & Ohio State University: Fisher & US \\
\hline 73 & University of Maryland: Smith & US \\
\hline 74 & SMU: Cox & US \\
\hline 79 & EMLyon Business School & France \\
\hline 81 & ESMT Berlin & Germany \\
\hline 81 & University of Texas at Dallas: Jindal & US \\
\hline 83 & Brigham Young University: Marriott & US \\
\hline 87 & Western University: Ivey & Canada \\
\hline 88 & AGSM at UNSW Business School & Australia \\
\hline 88 & Essec Business School & France \\
\hline 94 & University of Toronto: Rotman & Canada \\
\hline 96 & University of California at San Diego: Rady & US \\
\hline 100 & University of Georgia: Terry & US \\
\hline
\end{tabular}


Table 6 Cluster 2 Business Schools having both Vision and Missions Statements

\begin{tabular}{|c|c|c|}
\hline $\begin{array}{c}\text { FT Rank } \\
2020\end{array}$ & Business School \& University & Country \\
\hline 5 & CEIBS & China \\
\hline 9 & HEC Paris & France \\
\hline 13 & IESE Business School & Spain \\
\hline 15 & National University of Singapore Business School & Singapore \\
\hline 16 & Dartmouth College: Tuck & US \\
\hline 23 & Cornell University: Johnson & US \\
\hline 25 & IMD Business School & Switzerland \\
\hline 27 & Indian Institute of Management Bangalore & India \\
\hline 28 & Indian School of Business & India \\
\hline 37 & Shanghai Jiao Tong University: Antai & China \\
\hline 38 & Renmin University of China Business School RMBS & China \\
\hline 39 & University of North Carolina: Kenan-Flagler & US \\
\hline 40 & Indiana University: Kelley & US \\
\hline 42 & Indian Institute of Management Calcutta & India \\
\hline 43 & Warwick Business School & UK \\
\hline 44 & Washington University: Olin & US \\
\hline 45 & Alliance Manchester Business School & UK \\
\hline 47 & Shanghai University of Finance and Economics & China \\
\hline 50 & CUHK Business School & China \\
\hline 52 & IE Business School & Spain \\
\hline 55 & Imperial College Business School & UK \\
\hline 56 & HKU Business School & China \\
\hline 57 & University of Notre Dame: Mendoza & US \\
\hline 59 & Pennsylvania State University: Smeal & US \\
\hline 60 & Babson College: Olin & US \\
\hline 62 & Durham University Business School & UK \\
\hline 64 & WHU - Otto Beisheim School of Management & Germany \\
\hline 65 & University of California at Irvine: Merage & US \\
\hline 67 & Boston University: Questrom & US \\
\hline 71 & Mannheim Business School & Germany \\
\hline 74 & University of Pittsburgh: Katz & US \\
\hline 76 & University of Rochester: Simon & US \\
\hline 77 & University of Connecticut School of Business & US \\
\hline 78 & University of Minnesota: Carlson & US \\
\hline 84 & The Lisbon MBA Católica | Nova & Portugal \\
\hline 85 & Purdue University: Krannert & US \\
\hline 86 & Texas A \& M University: Mays & US \\
\hline 91 & McGill University: Desautels & Canada \\
\hline 92 & Wisconsin School of Business & US \\
\hline 93 & Miami Herbert Business School & US \\
\hline 95 & University of Edinburgh Business School & UK \\
\hline 97 & Macquarie Business School & Australia \\
\hline 98 & City University of Hong Kong & China \\
\hline 99 & University College Dublin: Smurfit & Ireland \\
\hline
\end{tabular}


Table 7 Cluster 3 - List of Business Schools having Vision Only

\begin{tabular}{|c|l|l|}
\hline $\begin{array}{c}\text { FT Rank } \\
2020\end{array}$ & \multicolumn{1}{|c|}{ Business School \& University } & \multicolumn{1}{c|}{ Country } \\
\hline 31 & Carnegie Mellon: Tepper & US \\
\hline 33 & Fudan University School of Management & China \\
\hline 40 & University of Texas at Austin: McCombs & US \\
\hline 53 & Georgia Institute of Technology: Scheller & US \\
\hline 61 & Indian Institute of Management Ahmedabad & India \\
\hline 68 & University of St Gallen & Switzerland \\
\hline 69 & Northeastern University: D'Amore-McKim & US \\
\hline 80 & Melbourne Business School & Australia \\
\hline 88 & Edhec Business School & France \\
\hline
\end{tabular}

Table 8 presents cluster wise information of most frequently used words. Different cluster presents almost similar patterns of most frequent words total information mentioned Table 3. Four keywords are common in both vision and mission statements including 'business', 'research', 'leader', and 'world'. Two keywords are distinct; 'students' appeared among vision statement and 'knowledge' appeared more in mission statements.

Table 8 Comparisons of Business School Clusters based on most frequent keywords

\begin{tabular}{|c|c|c|}
\hline \multirow[t]{2}{*}{ Cluster Information } & \multicolumn{2}{|c|}{ Five most frequently used words } \\
\hline & Vision & Mission \\
\hline \multirow{5}{*}{$\begin{array}{l}\text { Cluster } 1 \\
\text { Business Schools having Mission Statements Only } \\
\text { Number of Business Schools }=47 \\
\text { Average Rank }=43\end{array}$} & & Business \\
\hline & & World \\
\hline & & Leaders \\
\hline & & Research \\
\hline & & Knowledge \\
\hline \multirow{5}{*}{$\begin{array}{l}\text { Cluster } 2 \\
\text { Business Schools having both Mission \& Vision } \\
\text { Statements } \\
\text { Number of Business Schools }=44 \\
\text { Average Rank }=56\end{array}$} & Business & Business \\
\hline & Research & Research \\
\hline & World & Leaders \\
\hline & Leaders & World \\
\hline & Students & Knowledge \\
\hline \multirow{5}{*}{$\begin{array}{l}\text { Cluster } 3 \\
\text { Business Schools having Vision Statements Only } \\
\text { Number of Business Schools }=9 \\
\text { Average Rank }=58\end{array}$} & Leaders & \\
\hline & Business & \\
\hline & Research & \\
\hline & Students & \\
\hline & World & \\
\hline
\end{tabular}




\section{Conclusions}

This paper attempts to answer seven myths about vision and mission statements by analysing the vision and mission statements of Top 100 Business Schools in the world.

Myth 1: All business schools have both vision and mission statements.

False. Based on the analysis presented earlier (Fig 1; Table 5,6 \& 7) 47\% business schools have only mission statements; $44 \%$ business schools have both mission and vision statements; and only $9 \%$ business schools have only vision statements.

Myth 2: Both mission and vision statements are equal in length.

False. Vision statements are shorter in length as compared to corresponding mission statement (Table 4). Vision statements have relatively simpler text with multiple words reused.

Myth 3: All nine components must be present in all mission statements.

False. Not all nine components are replicated in all FT Ranked Top 100 Business school's mission statements (Table 3 ).

Myth 4 Faculty is the hallmark of business school's mission.

False. Concern for faculty and staff has only 13\% presence in FT Ranked Top 100 Business school's mission statements (Table 3).

Myth 5 Technology is at the centre stage of business school's mission.

False. Technology is the least mentioned item among nine components in FT Ranked Top 100 Business school's mission statements (Table 3).

Myth 6 Research is not part of business school's mission.

False. Research is one of the four most important keywords used in FT Ranked Top 100 Business school's mission statements (Table 3).

Myth 7 Leadership is no more part of business school's mission.

False. Leadership is one of the four most important keywords used in FT Ranked Top 100 Business school's mission statements (Table 3).

\section{Recommendations}

This paper supports recommendations provided by earlier research on the subject area [25]. Firstly, it supports the development of separate criteria to evaluate mission and vision statements for academic institutions.

It also supports the recommendation of need for uniqueness by Business Schools. Under the prevailing situation and competitive market, it is a very difficult situation for business schools to differentiate among other business schools. Now it is time for Business schools decision makers including deans, directors and other senior members to create uniqueness in their business schools, starting with uniqueness mission statements.

\section{References}

1. FT Business School Ranking, available at: http://rankings.ft.com/businessschoolrankings/rankings (2020)

2. T. Bayrak. A content analysis of top-ranked universities' mission statements from five global regions. International Journal of Educational Development, 72, 102-130 (2020).

3. M. Breznik, K. M. Law. What do mission statements reveal about the values of top universities in the world?. International Journal of Organizational Analysis. 27, 13621375 (2019). 
4. Taş, M. A., Çiçek, H., \& Yastioğlu, S. The Future In The Context Of Mission, Vision And Goals: Case Of Mehmet Akif Ersoy University Strategic Plan Studies (2020).

5. J. Jungblut, M. Jungblut. All different? All equal? differentiation of universities' mission statements and excellence initiatives in Germany. Science and Public Policy, 44, 535-545 (2017).

6. R. M. Lewkonia. The missions of medical schools: The pursuit of health in the service of society. BMC Medical Education, 1, 1-7 (2012).

7. J. Organ. Missing missions: Further reflections on institutional pluralism (or its absence). Journal of Legal Education, 60, 157-167 (2010).

8. E. A. Wilkerson, C. A. Evans. A content analysis of mission statements in nonprofit education. The Journal of Nonprofit Education and Leadership, 8 (2018).

9. E. Dedousis. An Analysis of Mission Statements of Tertiary Institutions: Business Colleges in UAE. e-Journal of Business Education and Scholarship of Teaching, 12, 31-51 (2018).

10. P. Mburu, T. Matenge, D. Amanze, R. Makgosa. Corporate branding in Botswana: A content analysis of visual brand elements. Journal of Business Theory and Practice, $\mathbf{1}$, 262-284 (2013).

11. David, M. E., David, F. R., \& David, F. R. Mission Statement Theory And Practice: A Content Analysis And New Direction. International Journal of Business, Marketing, \& Decision Science, 7, 2014.

12. K. Neuendorf. The content analysis guidebook Sage Publications, Inc. In Library of Congress. CA: United States (2002).

13. Peyrefitte, J., David, F. R. A content analysis of the mission statements of United States firms in four industries. International Journal of Management, 23, 296 (2006).

14. Bartkus, B. R., Glassman, M., McAfee, R. B. A comparison of the quality of European, Japanese and US mission statements:: A content analysis. European Management Journal, 22, 393-401 (2004).

15. Crawford Barniskis, S. Deconstructing the mission: A critical content analysis of public library mission statements. The Library Quarterly, 86(2), 135-152 (2016).

16. Cortés Sánchez, J. D. Mission statements of Top 100 Global Brands worldwide: Text mining and visualization. Intangible Capital, 14, 584-603 (2018).

17. Holosko, M. J., Winkel, M., Crandall, C., \& Briggs, H. A content analysis of mission statements of our top 50 schools of social work. Journal of Social Work Education, 51, 222-236 (2015).

18. Creamer, E. G., \& Ghoston, M. Using a mixed methods content analysis to analyze mission statements from colleges of engineering. Journal of Mixed Methods Research, 7, 110-120 (2013).

19. M. Hladchenko. The organizational identity of Ukrainian universities as claimed through their mission statements. Tertiary Education and Management, 22(4), 376-389 (2016).

20. Deus, R. M., Battistelle, R. A. G., \& da Silva, G. H. R.. Sustainability insights from the mission statements of leading Brazilian Universities. International Journal of Educational Management, (2016).

21. J. R. Warchal, A. I. Ruiz, D. You. Do Psychology Department Mission Statements Reflect the American Psychological Association Undergraduate Learning Goals?. Psychology Learning \& Teaching, 16, 369-374 (2017).

22. G. Mazurek, P. Korzynski, A. Gorska, A. Palyga. Mission statements in FT ranked European Top 100 Global Brands-a content analysis. European Research Studies Journal, XXIII (1), 639-649 (2020).

23. B. Orwig, R. Z. Finney. Analysis of the mission statements of AACSB-accredited schools. Competitiveness review: An International Business Journal, (2007). 
24. K. Falah, K. Siddiqui, Analyzing Mission Statements of Universities in Saudi Arabia, Academy of Strategic Management Journal, 20, 1-11 (2021)

25. F. David, \& F.R. David. Strategic management: A competitive advantage approach, concepts and cases. Florence: Pearson-Prentice Hall (2016). 